\title{
Comparative study of foraging behavior of Apis mellifera L. at two different agro climatic conditions in different seasons
}

\author{
Muhammad Younas ${ }^{1}$, Muhammad Israr ${ }^{2}$ and Yasir Ali $^{3 *}$ \\ 1. Agricultural Research Institute Tarnab Peshawar, Pakistan \\ 2. Government of Khyber Pakhtunkhwa Agriculture, Livestock and cooperation department, Peshawar, Pakistan \\ 3. The University of Agriculture Peshawar, Pakistan \\ *Corresponding author's email:yasirnsr73@gmail.com
}

\section{Citation}

Muhammad Younas, Muhammad Israrand Yasir Ali. Comparative study of foraging behavior of Apis mellifera L. at two different agro climatic conditions in different seasons. Pure and Applied Biology. Vol. 11, Issue 2, pp548-552. http://dx.doi.org/10.19045/bspab.2022.110054

\begin{tabular}{llll}
\hline \hline Received: 28/05/2021 & Revised: 16/07/2021 & Accepted: 30/07/2021 & Online First: 26/08/2021 \\
\hline \hline
\end{tabular}

\section{Abstract}

The research was conducted at two different climatic conditions, Agricultural Research Institute Tarnab Peshawar and AkoraKhattak, Nowshera during 2020. The study was aimed to compare the foraging behavior of Apismellifera $\mathrm{L}$. at different agro climatic conditions in different seasons (Acacia modesta and Zea mays). Peak foraging activity of pollen collectors in Acaciamodesta season was observed between 08:00 to 10:00 am (14.68 No. of bees/ 10 mins) followed by 10:00 to $12: 00 \mathrm{pm}$ ( $8.18 \mathrm{No}$. of bees/ $10 \mathrm{mins})$ then 12:00 to 2:00 pm (6.49 No. of bees/ 10 mins) while decline was recorded at 2:00 to 4:00 pm (5.75 No. of bees/ 10 mins). Similarly, maximum number of nectar collectors was observed from 12:00 noon to 2:00 pm (25.04 No. of bees/ 10 mins) followed by 10:00 am to $12 \mathrm{pm}$ (17.80 No. of bees/ 10 mins) then 2:00 to 4:00 pm (12.24 No. of bees/ 10 mins) and minimum number of nectar collection was noticed from 8:00 to 10:00 am (10.54 No. of bees/ 10 mins). The present research work concluded that peak pollen foraging activity was recorded at morning whereas the rest of day bees focused on nectar collection. The present study suggested in order to curb this problem, whole scientific community should get united to counter climate change.

Keywords: Acacia modesta; Apis mellifera; foraging behavior; Zea mays

\section{Introduction}

Honey bees known as social insects [1]. They belong to order Hymenoptera, family Apidae and genus Apis [2]. Apis species are further divided into 3 groups viz., the cavity nesting bees containing Apis mellifera, A. cerana, A. koschevnikovi, A. nigrocincta and $A$. nuluensis, open nesting the dwarf bees are; $A$. florae and $A$. andreniformis and the giant bees; A. dorsataand A. laboriosa. A. mellifera and $A$. cerana have been domesticated out of these above nine honey bee species [3]. There are three different specialized categories known as castes containing queen, drones and workers. Its improvement depended upon the food they are fed [4].

They fed their food in the type of nectar and pollen, thus a honeybee colony has diverse set of workers having duties to gather nectar, pollen and sometimes both of them [5]. Pollen is considered as basic source of protein, lipids, minerals and vitamins, 
whereas, nectar is made of sugar and water. Collecting of pollen and nectar from flowering plants by bees is known as 'foraging behaviour' [6]. Initial two or three weeks of their life cycle worker bees typically begin brood care and then become forager bee [7]. Foragers are categorized as scout bees which done their duty in a form of dancing [8]. Around 25\% of adult bees are foragers in a single colony [9] whereas reticent honey bees are around 40 to 90 percent to the sum of forager population [8] and 20 percent of bees store the food [10]. In normal bee colony status, worker bees, referred to as a forager bee, in the age of 21 days, at which they done their job outside the colony containing pollen, nectar, water, and resin collection [11]. Honey bees are naturally important pollinator; the main importance of honeybee is pollination activity while secondary is its valuable hive products [12]. Honey bees collect pollen from different plants around the year, collection of pollen is depending upon honey bee health, honey bee race, an environmental situation and planting area surrounding the honeybee colonies [13]. In honeybees, consumption of pollen is highest in young adults to enable their hypophryangeal gland to produce. Royal jelly for feeding larva's, after the transition to foraging at two weeks they consume mainly carbohydrates [14]. Pollen quantity and brood in the colony shows its status and can be used to expect the honey yield produced at the end of season. Multiple studies recorded positive correlation in stored pollen, brood production and honey yield [15]. Pollen absence for a longer period may decrease the quantity of brood reared in colonies [16]. Nutritional value of pollen is different in different plant species [17]. There is relationship between pollen nutrition value and development, reproduction and productivity of bee colonies [18]. Pollinating activity occurs in the early spring to the midautumn under diverse temperature climatic situation. Therefore, honeybees may description to the repetitive applications of pesticides. Apis mellifera is social insect which can be used to examine the environmental effects of parasites and pesticides because to its well-described natural history and easy to sustain in experiment [19]. Therefore, this study attempts to compare foraging activities of honey bee (Apis mellifera L.) under field condition during differentagro climatic conditions of KP province, during two different seasons (Acacia modesta and Zea mays).

\section{Materials and Methods Study area}

The current research was conducted in Acacia modesta grown at Akorakhattak, Nowshera, and Zea mays crop grown at the Agricultural Research Institute, Tarnab, Peshawar, during 2021.

Foraging behavior of the Honey bees (Apis mellifera L.)

Four honey bees (Apismellifera L.) colonies with equal number of worker bees, food and the brood comb were shifted to the trial site when the crop was in flowering stage.

Hive access of each colony was outfitted with pollen traps to study the efficacy of pollen and foraging pattern of Apis mellifera $\mathrm{L}$. Returning forager bees containing pollen loads and nectar were recorded for 10 minutes duration on hourly basis with different respective time of observation from 08:00-10:00 hours, 10:00-12:00 hours, 12:00-02:00 hours to 02:00-04:00 hours on regular basis in flowering stages for both seasons (Zea mays and Acacia modesta).

Data were observed in two different steps for foraging pattern 1) the entrance of colonies was equipped with pollen traps, 2) countdown pollen foragers during returning to the hive [20]. 


\section{Statistical analysis}

The data were subjected to statistical analysis using Graphpad Prism software for mean $\underline{ \pm}$ S.E and ANOVA.

\section{Results and Discussion}

Mean foraging activity of Apis melliferain Acacia modesta season

Seasonally, A. mellifera foraging in Acacia modestacrop shows in (Figure 1) reveal the number of foragers, pollen collectors and nectar collectors. The peak foraging hours was recorded from 08:00 to 10:00 am (14.68) followed by 10:00 to $12: 00$ (8.18) then $12: 00$ to $2: 00 \mathrm{pm}(6.49)$ while the least pollen collectors were recorded at the end of observation from 2:00 noon to $4: 00 \mathrm{pm}$ (5.75). Beside these, peak nectar collectors were recorded during 12:00 to $2: 00 \mathrm{pm}$ (25.04) followed by $10: 00$ am to $12: 00 \mathrm{pm}$ (17.80) then $2: 00$ to $4: 00 \mathrm{pm}$ (12.24) while the least number of nectar collectors was observed at the observation initiation from 8:00 to 10:00 am (10.54). Current research is in line with Tanda and Goyal [21] findings, theystudied the differences that were observed between the species with respect to times of initiation and cessation of foraging agree with the data. These authors observed Apiscerana. indicabetween 09.00 and 11.00 and A. melliferabetween 09.00 and 13.00 on Gossypiumsp. The differences in foraging preference may have reflected a difference in temperature preference.

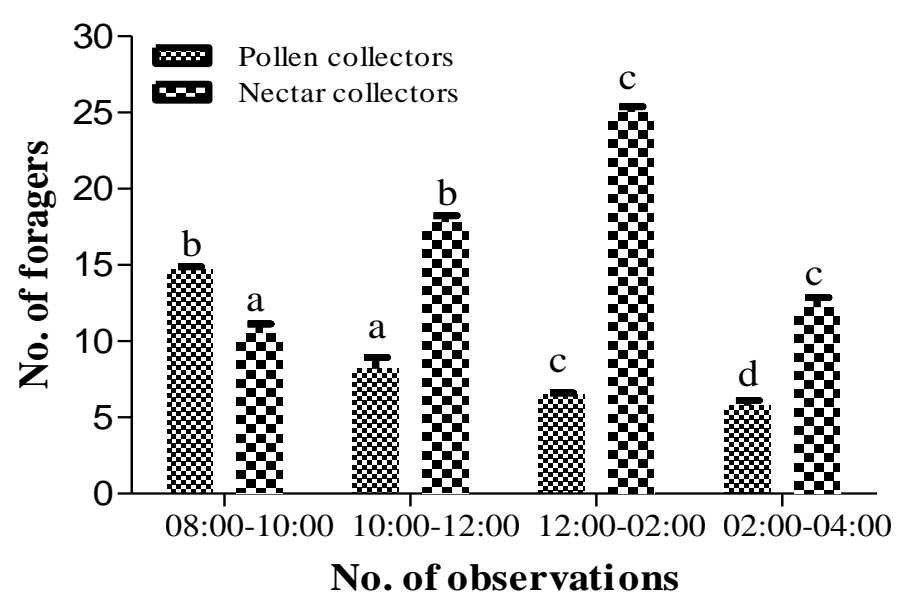

Figure 1. Seasonal A. mellifera foraging activities in Acacia modesta

\section{Mean foraging activityofApismellifera in Zea mays season}

Seasonally, A. mellifera foraging in Zea mays crop, the (Figure 2) showed the number of foragers; pollen collectors and nectar collectors. The peak pollen foraging hours was recorded 8:00 to 10:00 (20.18) followed by $10: 00$ to $12: 00$ am $(17.14)$ then $12: 00$ to 2:00 pm (6.05) while the least pollen collectors were recorded at the end of observation 2:00 noon to 4:00 pm (3.48) beside these peak nectar collectors was recorded during $12: 00$ to $2: 00 \mathrm{pm}$ (6.91) followed by $2: 00$ to $4: 00 \mathrm{pm}$ (4.37) then
10:00 am to $12: 00 \mathrm{pm}$ (3.05) while the least number of nectar collectors was observed at the observation initiation from 8:00 to 10:00 am (2.02). Our findings are in line with Verma and Dulta [22] finding the similar observation periods of foraging activities was noticed in his experimental trials. Similarly, Varma and Dulta [22] reported that similar foraging pattern of Apismelliferaat different time intervals. Thus its concluded from previous experiments that peak pollen forager was recorded at morning while peak nectar collector was observed at noon [22]. 


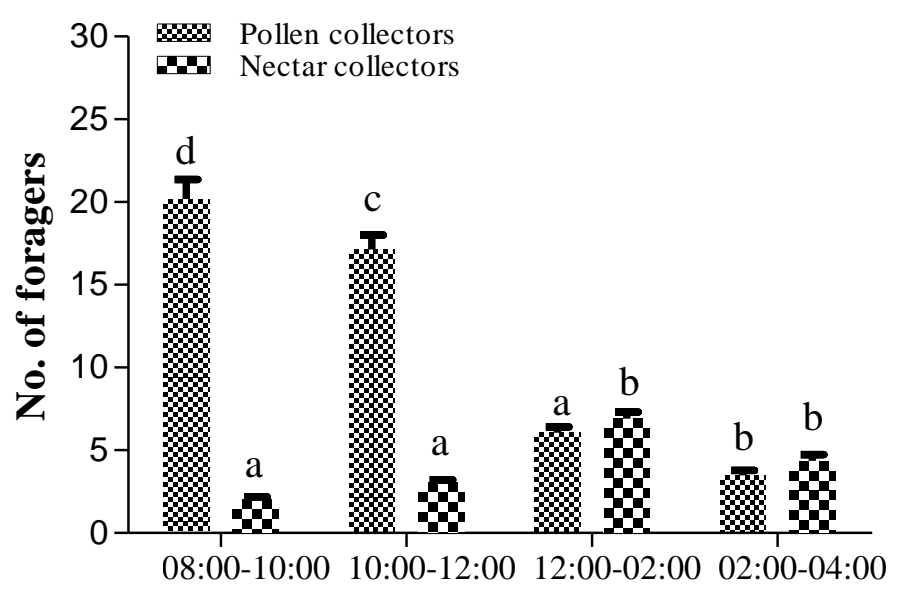

No. of observations

Figure 2. Seasonal A. mellifera foraging activities in Zea mays crop

\section{Conclusion and Recommendations}

The present study concluded that peak pollen foraging activity was recorded at morning whereas the rest of day bees focused on nectar collection. Due to increasing temperature pollen collection get effected. In current climate change scenario, the activity of pollen collection and pollination get affected by increasing temperature. Additionally, it also has bad impact on honey production. In order to curb this problem, whole scientific community should get united to counter climate change.

\section{Authors' contributions}

Conceived and designed the experiments: $\mathrm{Y}$ Ali, Performed the experiments: Y Ali, Analyzed the data: Y Ali, Contributed materials/ analysis/ tools: M Younas \& M Israr, Wrote the paper: Y Ali, M Younas \& M Israr.

\section{References}

1. Ruttner F \& Maul V (1983). Experimental analysis of the reproductive interspecific isolation of Apismelllifera L. and Apiscerana F. Apidol 14: 309-327.

2. Arias MC \& Sheppard WS (2005). Phylogenetic relationships of Honeybees (Hymenopter: Apidae: Apis) inferred from nuclear and mitochondrial DNA sequence data. Mol Phylog Evol 37(1): 25-35.

3. Koeniger N (1976). Interspecific competition between Apis florae and Apismellifera in the tropics. Bee World 57: 110-112.

4. Mishra RC \& Sharma SK(1997). Technology for management of Apismellifera in India. In: R. C. Mishra (ed.). Perspectives in Indian Apiculture. Agro Botanica, BikanerIndia 131-148.

5. Free JB (1993). Insect pollination of crops. Academic Press, London. pp. 684.

6. Gary NE(1992). Activities and behaviour of honey bees. In: The hive and honey bee (ed. Dadant and Sons). Dadant and Sons, Hamilton: Illinois, USA.

7. Toth AL, Kantarovich S, Meisel AF \& Robinson GE (2005). Nutritional statusinfluences socially regulated foraging ontogeny in honey bees. $J$ Exper Biol 208: 4641-4649.

8. Nest BNV \& Moore D (2012). Energetically optimal foraging strategy is emergent property of time-keeping behavior in honey bees. Beha Eco 23: 649-658.

9. Dreller C, Page JRE \& Fondrk MK (1999). Regulation of pollen foraging in honey bee colonies: effects of young 
brood, stored pollen, and empty space. Behav Ecol Socio Biol 45: 227-233.

10. Seeley TD (1989). Social foraging in honey bees: how nectar foragers assess their colony's nutritional status. Behav. Ecol Socio Boil 24: 181-199.

11. Huang ZY \& Robinson GE (1996). Regulation of honey bee division of labor by colony age demography. Beha Ecol and Socio Biol 39: 147-158.

12. Dhakal GC (1982). A comparative study of Apiscerana F. and Apismellifera L. on pollination of Brassica campestris Var. toria and Fagopyrum esculentum, M. at Rampur, Chitwan. M.Sc.In Entomology Thesis TU.IAAS Rampur, Chitwan, Nepal. pp. 76.

13. Hassan AR, Fathy HM, Bayoumy MH \& Tony ETAE (2015). Studies on activity of honeybee in collecting and storing pollen grains during spring and summer seasons. J Plant Prot Path Mansoura Uni 6(2): 255-268.

14. Brodschneider R \& Crailsheim K (2010). Nutritional and health in honey bees. Apidologie 41: 278-294.

15. Jevtic G, Mladenovic M, Nedic N, Sokolovic D \& Strbanovic R (2009). The correlation between colony strength, food supply and honey yield in honey bee colonies. Biot Anti Husb 25: 1141-1147.
16. Stroykov S (1963). Digestibility of pollen by the bees. Beekeeping 4: 23-25.

17. Day S, Beyer R, Mercer A \& Ogden S (1990). The nutrient composition of honey bee collected pollen in Otago, New Zealand. J of Apic Res 29: 138-146.

18. Radev Z (2018). Relation between amount of collected pollen by the honey bee (Apis mellifera L.) and its protein content. Ecol Eng and Envi Prot 4: 10-16.

19. Neumann P \& Carreck NL (2010). Honey bee colony losses. J Apic Res 49: 1-6.

20. Cartin W, Bommarco R, Carré G, Lamborn E, Morison N, Petanidou T, Potts SGSG, Roberts SG, Szentgyorgvi $\mathrm{H}$, Tscheulin $\mathrm{T}$, Vaissiere BE, Woyciechowski M, Kunin WE, Settele J \& Dewenter IS (2008). Measuring bee diversity in different European habitats and biogeographical regions. Ecol Monogr 78: 653- 671.

21. Tanda AS \& Goyal NP (1979). Preliminary observation on the effect of intervarietal bee pollination of desi cotton (Gossypiumarboreum Linn.). Indi $J$ of Entomol 41: 281-282.

22. Verma LR \& Dulta PC (1986). Foraging Behaviour of Apis cerana indica and Apis mellifera in Pollinating Apple Flowers. J of Apic Res 25(4): 197201. 